DOI: 10.20472/IAC.2017.33.054

\title{
OZLEM OZGUR
}

Selcuk University Communication Faculty, Turkey

\section{FATHER FIGURE IN TURKISH CINEMA}

\begin{abstract}
:
In terms of field of research, communication has a wide data source. Various topics ranging from communication between individuals to mass communication can be studied. One of the rich sources of data in this field is the cinema, which bears the features of the seventh art through its products and massively popularizes its message and constitutes one of the important branches of the entertainment industry.

In this study, the representation codes of the concept of fatherhood which is supposed to be a milestone of manhood and an indicator of the establishment of manhood for every man, that exist within Turkish cinema will have been analyzed. With reference to what the basic elements that reproduce the fatherhood in Turkish cinema are, the main cause of this study is to explore how the types of the representation of fatherhood occur within the sample movies. This study, moreover, seeks for an answer about what kind of a relationship exists between the father figure within the cultural structure of Turkish society and the representations of fatherhood that are presented in Turkish cinema.
\end{abstract}

\section{Keywords:}

Father, Father figure, Turkish cinema

\section{JEL Classification: L82}

This study was produced from a doctoral dissertation accepted by Sociological Sciences Institute of Anadolu University. In addition, this study was supported by Anadolu University Scientific Research Supporting Commission (Project no: 1407E342). 


\section{Introduction}

While sex in general terms is a definition made depending on completely biological differences gained by birth like being male or female, social gender is based on the definitions of the social structure regarding womanhood and manhood. Indoctrinating men to be strong and successful and opening the doors of the public sphere to them, the social order subordinates the woman by assigning passive roles to her. This state is a natural outcome of patriarchal structure. In fact, the absolute performance expected by the society and the family is a serious problem for men.

For this reason, it is highly important not only to understand and explain women, but also to figure out and clarify how men, who have the power and are seen as the advantageous party, constitute and maintain their masculine status of power. As the experiences of men are explained and examined, the codes of the patriarchal structure will be more easily solved. In Turkish society, the codes of the patriarchal structure are hidden in four important stages. The first of these is circumcision, the second is compulsory military service, the third is finding a job and the fourth is marriage and having children, that is, being a father. The status of fatherhood is deserved by a male who was circumcised, did his military service, and has a job and heterosexual sex experience. Although fatherhood is a sophisticated institution in political, social and psychological terms, it is quite often constituted in a fragile, unsuccessful or problematic way. Although there are serious studies regarding the male subject who is the potent holder of power, the comprehensive studies on fatherhood, which constitutes an important aspect of manhood, are not at an adequate level. The institution of fatherhood has sophisticated aspects which need to be discussed and examined by several disciplines.

In terms of field of research, communication has a wide data source. Various topics ranging from communication between individuals to mass communication can be studied. One of the rich sources of data in this field is the cinema, which bears the features of the seventh art through its products and massively popularizes its message and constitutes one of the important branches of the entertainment industry.

In the present study, the representation codes of fatherhood, which is an important turning point of manhood and an indicator of the successful construction of manhood for every man, will be analyzed in Turkish cinema. Films contain open and implicit messages regarding fatherhood. For this reason, the representations of fatherhood in Turkish cinema are an important point to be emphasized.

This study is academically nourished by the theoretical approaches towards social gender and aims to present the ways in which fatherhood is represented in Turkish cinema. 


\subsection{Status of "Father" in Turkish Society and It's Representation in Cinema}

In Turkish society paternal authority has had a great importance in every era for the hierarchical continuity of the society, and respect to the father constitutes the basis of a family (Türkdoğan, 1992, s. 102-113). In a general overview, father representations in Turkish cinema are observed to be directly proportionate to paternal role in social meaning.

Over many years, father characters in Turkish cinema have had efficient and significant roles in their children's lives.

In the movies, they are not only safe guards playing key roles in solving their children's problems, but also represented as authoritarian personalities as well. Alongside authoritarian father representations, there also appear mean-spirited and weird characters that are unfair against their children, don't fulfill their responsibilities, and inflict violence. In Turkish cinema during the period until the 1950s, fathers had always been the ones who solve the conflict that occurred in the dramatic structure. The representation of father occurs as an authority which is difficult to stand against, as well as being a father figure which embodies elements of love and compassion. The authoritarian warmhearted father often played by Hulusi Kentmen is the ideal father model for society (Yağız, 2009, s. 86-93). Representation of paternity in Turkish cinema has continued in this way for many years.

With the social transformation that took place in Turkey in the 1950's, there also have been some changes in the role of father. One of the most important elements that triggered this change is the policies that encourage the use of technology in agriculture, which began in the 1950s. With the mechanization of agriculture, the number of people employed in agriculture has declined and this created the need to work in other businesses. In accordance with this requirement, there has been a process of migration from rural to urban. In the following years of this process, the need for manpower in industrialized Western countries was covered by the Turkish workers. It's observed that father lost his power when family members other than men in the migrated families started working.It can be stated that, now the father has lost his significance and the distinction of being the person who provides the livelihood of the house, his power in the family has shaken and his absolute authority has started to resolve (Kandiyoti, 2010, s. 335-336; Kandiyoti, 2007, s.192-193; Tekeli, 2010, s. 107; Kaplan, 2004, s. 28).

The representation of the institution of paternity in the cinema in the 1960s was not very different from the social position of the father within that period. There are representations of father who lost his power and authority.

Two different child images of cultural universe of the 1970s are presented within the form and content of Turkish films in the 1970s. In the first image, there is a child who, rejecting the father, tends to establish the future on his own will, and is determined to be an adult. 
In the second image, however, there is a child who has an opposing attitude against those who contravene this authority, suppresses the desire to differentiate from father, and strives to identify with the father. This is the child who consistently avoids confronting the father Two different child images offer two different father images to the viewer. It is the figure of rejected father with a shaken authority, who is desired to be resembled and identified with (Arslan, 2004, s. 205).

In the representations of the 1980s' Turkish cinema, father cannot dispense justice. Instead of the fathers, children become the agents who keep and pull the family together. Gurbilek states that his orphanhood derives not from the lack of a real father but from the lack of a fair father (2004, s. 41-44).

Ulusay ((2004, s. 149-153) mentions a masculinity crisis in the Turkish cinema within the period starting from the 1990s through 2000s. It is obvious that women's success in economic and social life is the cause of this crisis. However, another reason for this crisis is the lack of paternity or a father figure. The lack of father within the movies occupies the narration as a serious issue. In the movies of this period, elder men shoulder the role of a father for younger men.

\section{Aim Method and Sample of the Study}

\subsection{The Aim of the Study}

This study aims to analyze the representation codes of the institution of paternity which is a significant milestone for manhood and an indication of how manhood is built for every man, in the Turkish cinema.

\subsection{The Sample of the Study}

The movies that were shot between the years 1960 and 2010 have been selected by purposive sampling method. These film are My Prostitute Love / Vesikali Yarim (1968), The Bride / Gelin (1973), My Aunt / Teyzem" (1986), Lobster Pot / Yengec Sepeti” (1994), Three Monkeys / Uc Maymun (2008),

\subsection{The Method of the Study}

In this study, qualitative case analysis is adopted to analyze the movies. In this method, the main concern focuses on how a specific situation occurs, evolves or whether it changes in the course of time. Researchers who adopt this method get into the data, then catch and discover the meaning (Neumann, 2009: 234-235). 


\section{STORYLINES OF SAMPLE MOVIES}

\subsection{Storyline of "Vesikalı Yarim/ "My Prostitute Love" Movie}

My Prostitute Love is a 'realist melodrama' that represents the sentiment of 60s' Istanbul in an authentic way. Poetically written and carefully crafted in cinematography, it juxtaposes the realist imagery of the 60s' diverse interiors and landscape with the mystical moments of love between a greengrocer and an escort, Halil and Sabiha, that come to life with the impressive performances of Turkan Soray and Izzet Gunay. Still remembered with its memorable dialogues and an insightful use of music, My Prostitute Love presents an oscillation between desire and withdrawal, and a long lasting doubt that pervades the story throughout; yet, it eventually succeeds in creating a rupture in the traditional moralist approach.

\subsection{Storyline of "Gelin" / "Bride" Movie}

A young woman moves with her husband and small child to her husband's family in Istanbul. Her son becomes ill and the doctor tells her that he will soon die if he doesn't get an operation. The family refuses to help her because they can't see anything wrong with the boy and all money is needed for a new shop they have just opened. When her son dies she takes a desperate step.

\subsection{Storyline of "Teyzem" / "My Aunt" Movie}

Üftade mother and stepfather lead an ordinary life. One day his elder sister, who had left home years ago, steals his doors with Umur. Umur and Üftade form a very sincere connection. A different face of Üftaden emerges with developing events. Because she have to live with her step father violence. And then She lost her control.

\subsection{Story Line of "Yengeç Sepeti" I "Lobster Pot" Movie}

An elderly couple invite their adult children to visit their country chateau. Among the children are Omer, his undemonstrative wife who knows about Omer's mistress, and Omer's children. The other son brings his seductive lover, and the daughter, a divorcee, brings her child. Mayhem ensues when their daughter's ex-husband makes a surprise appearance at the house.

\subsection{Story Line of "Üç Maymun"| " Three Monkeys" Movie}

A family suffers from a major communication breakdown during their struggle to get through their hardships. It is an effort to stay together, despite everything, by covering up the reality of a family whose little weakness has turned into big lies. They do not want to know espicially the father ignore, do not talk about, or play "Three Monkeys" 


\section{Findings and Conclusions}

The movie "My Prostitute Love / Vesikali Yarim" (1968) tells the story of a father who owns a greengrocery in Kocamustafa Pasa quarter of Istanbul and works together with his son.When his son who is married with two children involves with an escort girl whom he meets in a night club, it is the father who keeps the family together. He does not let his grandchildren feel the absence of their father.

He does not even say a word to his son. He does not assume any blaming attitude against his son. He treats his son who just got out of the prison as if nothing happened. He tells his son to concern himself with the business. Father authority constitutes the basis of this movie.It is the father who not only has the authority, but also solves the problems quietly. The son keeps doing his job feeling ashamed over the attitude of his father.

In the movie "The Bride / Gelin" (1973), the father appears in the center of the plans of expanding the business of the family which emigrates from Yozgat. The family, including the two sons, their wives and children, lives and works together. The father doesn't give money for his grandchildren's medical issue, though he is able to effort. The father uses the money to expand the business. He ignores the illness of his grandson. After the death of his grandson, he doesn't regret for what he has done. No one blames the head of the family except for the mother of the child. Father's authority is the absolute authority. The woman -the daughter in law, whose child dies, protests everything and starts working in a factory. Her husband also joins her. In the movie The Bride / Gelin, we observe a father who loses authority and power as a result of rural to urban migration. The authority he carried from village to city is shaken and he loses his powerful, problem solving status.

The movie "My Aunt / Teyzem" (1986) focuses on the story of the second marriage of a woman who is widowed with her three children after the death of her first husband, and what her family goes through. The children show respect to their father, even though he is their stepfather. The father is a source of authority. Two older children leave the house as soon as they find an opportunity; and every time they have a difficulty, the father starts scolding and taunting them. The younger daughter who lives with the father and the mother has to endure all the insults and despising of the father. As time passes by, she cannot get over the psychological problems that she experiences. The father's overoppressive attitude against his younger daughter prevents her from being successful. She cannot continue her marriage, nor can she take care of her child. In fact, none of the children may properly put their lives in order. Whilst the older children can take care of themselves, the youngest and the most vulnerable one has to undergo all of the negative behaviors of the father. Therefore, in Turkish cinema of the 1980s, children somehow 
have a father, but not a fair and competent one. Instead of solving the problems, the father himself becomes a source of problem and harm.

In the movie "Lobster Pot / Yengec Sepeti" (1994), we see a father who desires to spend his last days with his children. The father of four children who ensured all his daughters and sons have higher education is proud of himself and his wife, assuming all his children have peaceful lives. Everything changes during a weekend visit. The husband of his divorced older daughter comes out of the blue and all the arguments, accusations and violence disturb the peace of the family. The high point here is that the older brother tries to protect his sister and back her up. Taking care of his sister, he tries to show that he fills in for his father who is now getting older. He warns and preaches his siblings. However, when, at the end of an argument, he slaps his sister in the face, his father feels uncomfortable about this incident. The father removes his hearing instrument when he cannot end these arguments. He does not want to hear the voices which, in any case, he hardly hears. Even though the children apologize from each other, this does not satisfy the father. He realizes something is wrong with his family, but he is not strong enough. In the movie we see a father who has lost his power and authority, and a son who seeks to claim this power in place of his father. He tries to solve the problems in his own way, but he cannot succeed. In the 1990s, father is replaced by older brother who makes an effort to protect his siblings; however, he cannot succeed it.

In the movie "Three Monkeys / Uc Maymun" (2008), there is a father who is sentenced to prison taking the blame for his boss. The father tries to take care of his family even from the prison he is locked up as a result of taking the blame for a crime he did not commit. When he learns that his son could not succeed in the university entry exam, he advises him to study harder for the next year and pull it off. When their son Ismail is reluctant to take the exam, the mother tries to find a job for him. He tells his mother that they should ask for his father's money back from Mr. Servet. His mother does not accept this in any way. She says, "I would do nothing without your father's permission". It is observed that, the father still has an authority in the house regardless that he is in the prison. The mother goes to the office of Mr. Servet to ask for money. After that point, a relationship starts between the mother and Mr. Servet. Servet does not care about this relationship considering that the situation is just temporary. Things are different for the woman; she is defeated by her weakness, yet she struggles to get rid of the dilemma she has. When her husband comes out of the prison she cannot tell the truth to her husband in any way. The father realizes that something is wrong with his family, but he does not force them to confess. He is unable to keep his family together. He already has defeated by a more powerful man taking the blame for his crime. He has a loss of power. After the mysterious death of Mr. Servet, though everything comes to the light, no one clearly speaks about the situation. After the death of Mr. Servet, Eyup finds a man to take the blame, and he tries to convince him. The movie ends at this point. Manhood is used against not only women, but also other men of lower class status. Mr. Servet exercises a 
power trip of manhood against Eyup by using his economic power. When his wife is involved with Servet; Eyup loses the one power domain left in his hand: his wife. This drags him into a crisis of masculinity. Thus he tries to claim power over the lower status men by having someone take the blame for the murder. Within such an impasse, Eyup loses all his domain of power as a man. And he cannot even fulfill his paternal duties properly

\section{Conclusion}

In this study, representation of father has been analyzed in the movies of Turkish cinema produced between 1960 and 2010. It is observed in the movies that the power domains of the fathers narrow down day by day.

Apart from the movie "My Prostitute Love / Vesikali Yarim", we do not encounter an ideal figure of father. In the movie "My Prostitute Love / Vesikali Yarim", the father who makes up for his son's faults and keeps his family together, appears as a man who loses his power in the next years.

In the movie "The Bride / Gelin", the father is represented as the figure of authority. Though his older son accepts this authority and follows the path of his father, the younger son refuses the authority of the father after losing his own child. The fathers are no more dispensers of justice and the authorities to hold their families together. In the movie "My Aunt / Teyzem", this situation thoroughly makes itself evident. There actually is a figure of father. However, it is far from meeting the expectations of the children and the wives. It is also far from the idea of solving the problems.

In 1994 production "Lobster Pot / Yengec Sepeti", the father actually is an ideal figure. He has enabled his sons and daughters to receive decent education. He wants to support them while they try to solve the problems they have in their lives by themselves. But he is no more capable of that. Thus, the older son of the family assumes this duty.

This indicates that the duties assigned to the father are now shifting to brothers or friends. The representation of father in the movie "Three Monkeys / Uc Maymun" shows a man who already does not possess the proper qualifications as a man. This situation leads to a crisis.

The man who is unable to solve this crisis cannot be sufficient as a father, either.He makes all the sacrifices he can for his family; but yet he cannot prevent his family from falling apart. 


\section{References}

Arslan, U.T. (2005). Bu kabuslar neden Cemil. İstanbul: İmge Yayınları.

Gürbilek, N. (2004) Kötü çocuk Türk. İstanbul: Metis Yayınları.

Ulusay, N. (2004). Günümüz Türk sinemasında erkek filmleri. Toplum ve Bilim Dergisi. 101, 144-161.

Türkdoğan, O. (1992). Türk ailesinin genel yapısı sosyal kültürel değişme sürecinde Türk ailesi. Ankara: T. C. Başbakanlık Araştırma Kurumu Yayınları.

Kandiyoti, D. (2007). Cariyeler bacılar yurttaşlar. İstanbul: Metis Yayınları.

Kandiyoti, D. (2010). Ataerkil örüntüler: Türk toplumunda erkek egemenliğinin çözümlenmesine yönelik notlar. Şirin Tekeli (Ed.), 1980'ler Türkiye’sinde kadın bakış açısından kadınlar içinde (s. 327-340) İstanbul: İletişim Yayınları.

Kaplan, N. (2004). Aile sineması yılları 1960’lar. İstanbul: Es Yayıncılık.

Yağız, N. (2009). Türk sinemasında karakterler ve tipler. İstanbul: İşaret Yayınları.

Tekeli, Ş. (2010). 1980'ler Türkiye'sinde kadınlar. Ş. Tekeli (Ed.). 1980'ler Türkiye'sinde kadın bakış açısından kadınlar içinde (s. 15-46) İstanbul: İletişim Yayınları. 